\title{
MULHERES SEM-TETO E A GEOGRAFIA DA FAMÍLIA: RELAÇÕES INTERDOMÉSTICAS, GÊNERO E RECIPROCIDADE
}

- MARIANNA FERNANDES MOREIRA ${ }^{2}$

Resumo: Desde meados da sécula passada, uma série de autores (especialmente da antropologia, da saciologia e da história) começau a destacar a perigo da naturalização da família nuclear, e de sua utilizaçãa coma parâmetro de relações "adequadas" au "regulares". A geggrafia, apesar de não ter tomado a família como objeto de estudo, naturalizando a família nuclear, tem contribuído para a discussão sobre a casa e o lar (a " sua casa"), questionando sua compreensãa como esfera privada, separada da esfera pública da trabalha, da cidadania e da política. Todas esses trabalhas problematizam a visãa idealizada do lar, buscanda desconstruir suas características universais. Sem embarga, o "lar ideal" se encontra intimamente ligada à compreensão igualmente restrita da família: a da família nuclear. An compreender que a espacialidade da família não se esgata em sua unidade residencial, mas a extrapala, podemos apreender uma geografia que integra composições cambiantes de configurações familiares, práticas espaciais de alocação de pessaas e coisas, e papéis sexuais com espacialidades distintas, marcadas pelo lugar que acupam no grupo doméstico e por relações de presença e ausência, de permanência e impermanência. № escopo deste trabalho, busco investigar a dinâmica familiar a partir das transformaçães dos grupos damésticas, em contextos marcados pela instabilidade da moradia, como no caso dos sem-teto. ( artigo parte de alguns casos exemplares de trajetórias de vida de mulheres sem-teto para campreender camo o compartilhamenta, a gestão e o cuidada, que envolve pessaas, coisas e lugares, produzem afetividades, proximidades e distâncias, que compõem o pracesso cantínuo de farmaçãa da família e da lar.

Palavras-chaves: geografia da família; lar; sem-teto; relacionalidade; cuidado. 


\section{Lares e famílias "sem-teto": delimitando o tema da pesquisa}

A literatura sobre a formação da família é vastíssima. Quando o termo família nos vem à cabeça, recorremos imediatamente à representação de uma família composta por pai, mãe e filhos vivendo em uma casa, ou seja, a família nuclear. Contudo, desde meados do século passado, uma série de autores (especialmente da antropologia, sociologia e história) começou a destacar o perigo da naturalização da família nuclear, e de sua utilização como parâmetro de relações "adequadas" ou "regulares"'. Com um leque amplo de assuntos, acabaram por mostrar que, vista sob a lupa da teoria crítica, nenhuma "família" segue a narrativa linear padrão. A coletânea organizada por Janet Carsten (2000), Cultures of Relatedness, é uma das principais referências". Em seu artigo, Carsten (2000) traz o conceito de "relacionalidade" como uma trama de conexões que são costuradas nas práticas cotidianas, para contrapor a visão predominante do parentesco, centrada apenas no determinismo biológico da família nuclear.

\section{Luiz Fernando Dias Duarte} (1995) argumenta que o que chamamos de família no Ocidente moderno é exclusivo da nossa cultura e baseado em agenciamentos de valores próprios. Um dos elementos desse processo de construção da família nuclear vem da valorização desta como resultado e sinônimo de processos de modernização das sociedades (VIANNA, 2002). $\mathrm{Na}$ realidade, a família nuclear é um dos efeitos do processo de individualização característico da sociedade moderna, levando à fragmentação e à redução das unidades sociais à sua forma mais “indivisível”, fazendo com que a própria "família nuclear" possa corresponder a uma espécie de "indivíduo coletivo" (DUARTE, 1995).

Os hábitos cotidianos vinculados ao lar, hábitos estes compartilhados socialmente, ditam grande parte dos comportamentos individuais e fazem deste "espaço privado" um importante núcleo de organização da sociedade. A geografia, apesar de não ter tomado a família como objeto de estudo, naturalizando a família nuclear, tem contribuído para a discussão sobre a casa e o lar (a "sua casa”), desconstruindo sua compreensão como esfera privada, separada da esfera pública do trabalho, da cidadania e da política. Investigações em diferentes contextos históricos e contemporâneos têm questionado o caráter seguro e protegido da habitação (HOLLOWAY 1998, 1999; 
PRATT, 2002; YOUNG, 1997) e explorado a importância do trabalho remunerado e não remunerado dentro de casa; e as maneiras pelas quais práticas de construção do lar estão ligadas a ideias de cidadania e ao significado político do lar e da domesticidade.

Todos esses trabalhos problematizam a visão idealizada do lar buscando desconstruir suas características universais. Sem embargo, o "lar ideal" se encontra intimamente ligado à compreensão igualmente restrita da família: a da família nuclear. Sendo assim, é imprescindível desnaturalizar a família nuclear e, assim como o lar, compreendê-la como um processo que toma forma a partir de um fluxo de relações, tarefas, cuidados e obrigações, constituindo algo muito mais amplo e complexo do que os limites de uma moradia ou de um único modelo familiar.

Desnaturalizar a família nuclear significa revelar a relativa arbitrariedade das relações baseadas nos afetos domésticos que impõe uma forma de habitar, construir, se relacionar, e que, assim, também impõe uma única geografia. Apreendê-la como uma construção social e espacial é, neste sentido, não reduzir e limitar toda a reprodução da vida na modernidade a apenas um tipo de família moderna e a um tipo de habitação (a monoparental), mas compreender que o mundo da vida de um grupo social não pode ser feito sem levar em conta a geografia do mundo que eles constroem (HERBERT, 2000).

Além disso, como argumenta Sylvia Leser de Mello (2003 [1995]), o que incita mais a discussão e reflexão sobre as questões da família tem relação com alguns inquietantes sintomas de etnocentrismo ou do preconceito que se tem por determinados tipos de organização familiar, especialmente os das famílias das classes populares. Os hábitos e costumes das classes populares dificilmente são vistos como inseridos dentro de um contexto de diversidade cultural. Na grande maioria das vezes, acabam por serem alvo de intervenções repreensivas ou de "recuperação". As diferenças que são admitidas e evidenciadas são vistas como degeneradas ou patológicas, falhas de "nossa" organização social, mas que, na verdade, representam a organização social das classes dominantes.

Para falar de povos longínquos, agilizam-se conceitos tais como 'ritos agonísticos', 'sociabilidades tribais' e ‘famílias consanguíneas'. Chegando perto de casa, estes são substituídos por termos tais como 'violência', 'promiscuidade' e 'famílias 
desestruturadas'. (...) Relativizar as práticas de pessoas que partilham de nosso universo é questionar nossos próprios valores; é admitir as contradições de um sistema econômico e político que cria subgrupos com interesses quase opostos. Nossa abordagem não deve ser confundida com um relativismo simplista. Procurar compreender certas dinâmicas não significa louválas, nem advogar sua preservação. Significa, antes, olhar de forma realista para as diferenças culturais que existem no seio da sociedade de classe - sejam elas de classe, gênero, etnia ou geração; significa explorar o terreno que separa um indivíduo do outro na esperança de criar vias mais eficazes de comunicação. (FONSECA, 2004, p. 14)

Por isso, Sarti (2009) argumenta que é preciso buscar as nuances, os matizes e as especificidades que dão significado às relações familiares, sem reduzi-las à mera reprodução da dominação. Traduzindo um processo histórico específico em um valor moderno frente ao atrasado ou residual -, essa percepção acaba por dar fundamento a leituras dicotomizadas da pluralidade de famílias (VIANNA, 2002).

Embora o modelo de família imposto pela sociedade moderna (industrial, urbana, ocidental) preconize, implicitamente, que o grupo doméstico (formado por aqueles que vivem em uma mesma unidade doméstica) e a família são coextensivos e equivalentes, esta não é, necessariamente, uma característica correspondente às famílias das classes populares (WOORTMANN, 1987) - se é que podemos encontrá-la em qualquer grupo social. Primeiro, porque a família, compreendida de forma mais ampla, envolve um conjunto aberto de relações que são concebidas como relações biológicas entre os indivíduos (relações de sangue), as relações estabelecidas pelo casamento (aliança) e as relações "de consideração" (formada por vizinhos ou amigos que são considerados como “irmãos” ou “da família”) (DUARTE e GOMES, 2008). Segundo, porque os limites dos grupos domésticos são difíceis de serem delimitados, uma vez que a organização do grupo doméstico pressupõe uma relação interdoméstica, envolvendo uma malha mais ampla de relações entre pares, sobretudo quando se frustram as expectativas de se cumprir o modelo da família - e sua equivalência conceitual e coextensão com o grupo doméstico.

As famílias que foram objeto desta pesquisa apresentam dinâmicas movimentadas de reorganização do grupo 
doméstico. A instabilidade de moradia é certamente um fator que impulsiona tais reorganizações. Apreendê-las como unidades residenciais estáticas impede a compreensão de seu movimento cambiante característico. A organização do grupo doméstico destas famílias recorre, com frequência, a uma malha familiar mais ampla, e é marcada pela impermanência do homem. Os frequentes deslocamentos que a instabilidade de moradia impõe, além das condições materiais da família, fazem com que a gestão do grupo doméstico pela mãe implique colocar em movimento as pessoas e coisas que o compõem. Assim, no caso dessas famílias, o grupo doméstico nem sempre corresponde àqueles que habitam uma mesma unidade residencial. A necessidade de morar na casa de outro grupo doméstico, ou a inadequação da moradia a que têm acesso (por ser muito pequena, por exemplo), fazem com que as famílias realoquem objetos pessoais e crianças para colocá-los, mesmo que provisoriamente, sob os cuidados de outrem. As famílias sem-teto oferecem, portanto, um campo fértil para a pesquisa social sobre famílias de classes populares, uma vez que nos ajudam a questionar a concepção de lar e família como categorias universais representadas pelo modelo de família conjugal burguesa e da residência monoparental.
O presente artigo é parte da minha tese de doutorado (MOREIRA, 2016), fruto de um longo período de imersão no campo e na vida de um grupo formado por famílias de sem-teto. Todas as famílias compartilham de um mesmo passado recente, pois eram moradoras da Ocupação Quilombo das Guerreiras. Em outubro 2006, após duas tentativas frustradas, o grupo composto por cerca de 50 famílias ocupou o imóvel da Companhia Docas, localizado na Avenida Francisco Bicalho, próximo à Rodoviária Novo Rio. A referida ocupação, no entanto, foi despejada em fevereiro de 2014, e seus antigos moradores dispersaram-se pela cidade. Os moradores da Ocupação Quilombo das Guerreiras foram inseridos em um projeto de reassentamento aprovado pelo Ministério das Cidades que contemplaria a construção de 142 unidades habitacionais: $\mathrm{O}$ Projeto de Moradia Popular Quilombo da Gamboa. Atualmente, o projeto está inserido no "Programa Minha Casa, Minha Vida Entidades". Durante os quase sete anos e meio de existência, a Ocupação Quilombo das Guerreiras abrigou diversas pessoas e famílias: as que ocuparam o prédio, as que entraram depois de ocupado, as que saíram ao longo do caminho, as que permaneceram até o fim, as que continuam 
no Projeto de Moradia Popular Quilombo da Gamboa etc.

As estratégias que fundam, gerem e organizam o grupo doméstico formado são estabelecidas nos movimentos de negociações e tensões que envolvem relações de gênero, geração, sexualidade, classe, etnicidade etc., que acabam por relativizar as fronteiras da pessoa $\mathrm{e}$ ressignificar a família e o parentesco. Partindo de trajetórias individuais de mulheres sem-teto, busco pensar esse trabalho contínuo de formação da família e do lar a partir de diferentes percursos que se entrelaçam, muitas vezes impulsionados pelas relações de reciprocidade e de localidade. Tais processos são aqui pensados a partir dos deslocamentos espaciais, afetivos ou afetivo-espaciais e de aproximação ou distanciamento - no sentido de forjar, manter ou diluir os grupos domésticos. Os deslocamentos caminham concomitantemente às elaborações e às práticas dos projetos de vida que, moldados no curso das trajetórias, sempre esbarram nas situações impostas, obrigando sua reelaboração e a mudança de sua prática. O trabalho parte de alguns casos exemplares de trajetórias de vida para compreender como o compartilhamento, a gestão e o cuidado, que envolve pessoas, coisas e lugares, produzem afetividades - proximidades e distâncias - que compõem o processo contínuo de formação da família e do lar.

A próxima seção está dividida em três partes. A primeira tem como objetivo pensar a família em um sentido extenso, entendendo que os parentes têm um papel fundamental na organização do grupo doméstico ao suprir necessidades cotidianas imediatas, mesmo que isso prescinda de uma situação de coresidência. A gestão e a manutenção do grupo doméstico são marcadas por uma relação de interdependência com outros grupos domésticos para sua sustentação. A segunda parte diz respeito ao papel intermitente do homem no grupo doméstico. Apesar de darmos centralidade às mulheres para vermos as constantes transformações no grupo, as figuras masculinas estarão presentes para cumprir os papeis que lhe cabem neste processo. Por fim, a terceira e última parte aborda as relações mulher-mulher. A permanência feminina em relação ao grupo doméstico não é estática, pois o trabalho de gestão do grupo doméstico envolve um movimento frequente de circulação das coisas e pessoas que compõem o grupo, e que, além disso, aciona uma rede de mulheres (avós, mães, irmãs, primas, filhas e sogras) em diferentes momentos durante o percurso. 
A família como processo: trajetórias e projetos de vida

Para compreendermos o caráter dinâmico da organização familiar dos semteto, é preciso nos desfazermos da imagem estática da unidade doméstica, visto que as análises pautadas em "tipologias residenciais" - de diferentes categorias residenciais - se adaptam particularmente mal às populações pobres urbanas, uma vez que obscurecem aspectos fundamentais da organização do grupo doméstico: sua flexibilidade e suas mutações no tempo (FONSECA, 2004).

As trajetórias de vida das mulheres sem-teto são marcadas por deslocamentos. Suas vidas constituem uma linha sinuosa e imprevisível, ora impulsiva, tomada por paixões e decepções, esperança e desencantamento, e ora planejada, decidida ou mesmo conduzida por relações entre parentes. Ao moverem-se no tempo, linhas de vida entrelaçam-se, se encontram; mas também se apartam, rompem, sendo enfeixadas em combinações diversas. O geógrafo Hägerstrand (1982) afirma que a trajetória (path) abarca a continuidade de formulações de projetos (projects) que são (re)negociados a partir das situações (situations) impostas ao longo da vida. Os projetos, segundo o autor, são perseguidos continuamente no fluxo da vida. A partir da perspectiva espaço-temporal integrada de Hägerstrand, o lugar de origem e destino não são pontos que se conectam como em um mapa de uma rede de transporte, mas são contínuos que se tangem na medida em que são construídos, frustrados e reelaborados os projetos de vida. Os deslocamentos, portanto, não devem ser compreendidos unicamente a partir de um ponto de origem e de destino, uma linha ligando pontos, mas sim, como um percurso instável de idas e vindas, que ora avança pertinaz, teimoso, fugindo de um passado assombroso que se quer esquecer; e ora caminha hesitante, indeciso, como quando o estertor da saudade ou do desalento invoca o retorno.

Os parentes, muitas vezes, constituem um ponto de referência básico da fixação na cidade, assim como respondem satisfatoriamente às carências cotidianas, dentro de um paradigma composto por três elementos: dar, receber e retribuir (DURHAM, 1973). Dentro deste "código de reciprocidade", trocas de serviços e reparos domésticos são realizados, estabelecendo-se uma ajuda mútua que permite responder aos problemas mais imediatos. Ao falar sobre as relações pautadas na reciprocidade, sugiro que, ao invés de pensarmos que 
estas relações configuram uma rede, em que as bases de apoio e suporte seriam seus nós, proponho pensarmos em linhas de trajetórias distintas que se entrelaçam, muitas vezes impulsionadas pelas relações familiares e de localidade. As aproximações e distanciamentos, deslocamentos espaciais, afetivos ou afetivos-espaciais, caminham concomitantemente às elaborações e às práticas dos projetos de vida, que moldados no curso da linha-de-vida, sempre esbarram nas situações impostas, obrigando sua reelaboração e sua prática. Justamente por não estudar a família como categoria estática, mas os processos familiares, é que podemos ver sua cambiante formação: um processo conflituoso de construção de unidades, no sentido de mantê-las ou até diluí-las, que passa pela constituição de fronteiras, limites, hierarquias e jogos de possibilidades dentro de unidades que não são estáticas, mas dinâmicas e em constante transformação.

Os deslocamentos são impulsionados pelo contínuo processo de formulação de projetos de vida. Mais especificamente, no âmbito das relações domésticas e inter-domésticas, esses projetos são (re)formulados e colocados em prática, seja se deslocando - e colocando um novo projeto em marcha - ou no trabalho constante que sua manutenção demanda. A gestão e organização do grupo doméstico formado são estabelecidas no interior de relações que envolvem os papéis sexuais e relações interdomésticas. Contudo, o deslocamento espacial não é somente um produto da mudança no grupo doméstico, uma vez que a motivação de sua reorganização pode ser uma causa para o deslocamento. Ao deslocar-se, muitas vezes, torna-se imprescindível reorganizar o grupo doméstico, e da mesma forma, inúmeras vezes, será necessário o deslocamento para colocar em prática as transformações almejadas no grupo. Assim, tanto os deslocamentos espaciais (como as mudanças de casa) podem conduzir a mudanças no grupo doméstico, quanto a modificação dos grupos domésticos vinculada às aproximações e distanciamentos afetivos (especialmente entre casais) - pode, da mesma forma, impulsionar mudanças de casa. O objetivo é pensar como esse jogo composto por negociações das relações familiares e as mudanças de casa influenciam na organização do grupo doméstico. E, ao mesmo tempo, compreender de que forma a manutenção do grupo doméstico e sua própria dinâmica cambiante promovem deslocamentos espaciais das pessoas e coisas que o compõem, seja para fazer 
circular seus membros (promovendo uma dispersão espacial do grupo) ou reaglutinando num mesmo local, membros que se encontram dispersos espacialmente.

\section{A família de Daniela: conjugalidade e as} relações interdomésticas

Daniela, hoje com 52 anos, nasceu no bairro do Engenho Novo na cidade do Rio de Janeiro. Daniela saiu cedo da casa da mãe para morar com seu primeiro companheiro, com quem permanecera por cerca de 20 anos, até seu falecimento. Ao longo dos 20 anos de casamento, tiveram cinco filhos. O primeiro marido de Daniela, apesar de ser "um homem trabalhador" (como ela diz) e o principal responsável pela renda familiar, gastava muito do que ganhava com despesas particulares, o que diminuía consideravelmente a renda da casa. Daniela acabava se responsabilizando por uma parcela dos custos domésticos, trabalhando como faxineira "para ajudar" o marido. $\mathrm{O}$ fato de Daniela trabalhar fora - e, por isso, ficar longe de casa durante o dia - passou a ser um problema quando seus filhos, já crescidos, começaram a “andar com más companhias”. Sem poder contar com o marido para suprir todas as necessidades financeiras da família, para que ela pudesse "controlar os filhos",
Daniela aceita a ajuda oferecida por sua mãe: se reaproxima da família original, para que ela a ajudasse a vigiar os filhos enquanto estivesse trabalhando. Seu marido vende a casa em que moravam e constrói um andar em cima da casa da sogra.

A ida para a casa da mãe de Daniela configura uma mudança organizacional no grupo doméstico. Para compreender tal mudança, é preciso atentar para o fato de que os limites da família das classes populares ultrapassam as fronteiras da unidade doméstica, e esta extensão dos aspectos organizacionais é coerente com a extensão ideológica equivalente do próprio termo "família" (WOORTMANN, 1987). Como argumenta Duarte, as classes populares apresentam uma nuclearização independente da conversão à ideologia familialista, em que a preeminência da dimensão do grupo doméstico também é evocada (DUARTE, 1986). A família de classe popular conjugaria, para Duarte, a dimensão genérica do parentesco com a dimensão operacional do grupo doméstico, de modo a servir a essa reprodução estereotípica característica de todo o mundo social.

Para percorrer o processo de formação dos grupos domésticos é preciso compreender a dificuldade de traçar seus 
limites. Se existe uma organização doméstica, existe, também, uma organização interdoméstica, sendo a primeira, em boa medida, função da segunda (WOORTMAN, 1987). Contudo, Woortman ressalta que essa própria dificuldade aponta para a importância de tais situações como instâncias das quais se pode derivar os princípios que governam a organização familiar.

Tradicionalmente, a Antropologia considera a categoria de "família extensa" como uma unidade doméstica composta por uma família de três gerações. Não obstante, nas classes populares, as famílias extensas não só podem incluir outros membros não relacionados por parentesco (em sentido estrito), como também, podem não habitar uma mesma moradia, visto que a organização interdoméstica se faz presente no fluxo contínuo de bens e serviços em circulação recíproca entre unidades residenciais aparentadas. Assim, o grupo doméstico (seja ele conjugal ou não) é, não raro, isolado tão somente no que concerne à residência. Por isso, a autora propõe distinguir os termos "família doméstica" - grupo de parentes e seus dependentes que constituem um grupo doméstico - e "família extensa", isto é, um conjunto de parentes que constituem o círculo interior de uma rede de parentesco. Esta deve ser entendida no sentido de "família em sentido extenso". Para os casos em que o grupo doméstico é composto por uma família extensa, no sentido antropológico usual, a autora utiliza o termo "família extensa doméstica”. De todo modo, como observa Woortman, deve-se ter em mente que entre "família extensa" e "família extensa doméstica” existe uma conexão estrutural, visto que a segunda é um arranjo residencial baseado nos princípios da primeira.

A mudança de Daniela e de seu grupo doméstico para a casa de sua mãe, promove esta transição de "família extensa" (dado os estreitos laços compartilhados entre os parentes matrilaterais) para uma "família extensa doméstica”. A transição, porém, não ocorre sem atritos, visto que a presença do marido de Daniela na casa de sua mãe é interpretada pelo irmão de Daniela como uma ameaça à manutenção da propriedade da casa por sua família. Ao mesmo tempo, o conflito e a constante afirmação da exterioridade do marido de Daniela em relação à habitação ressaltam a sua perda de autoridade perante seu próprio grupo doméstico, pois não mais exerce o papel de "dono da casa".

Após problemas com o irmão de Daniela, seu marido rompe com a família da esposa e compra um "barraquinho 
debaixo do viaduto em Inhaúma”. Entretanto, Daniela não aceita ir morar com o marido (que leva os dois filhos mais velhos) e permanece com sua filha na casa da sua mãe. Passados poucos meses morando separados, ela decide "ir para junto do marido", refundando o grupo doméstico com o marido, sua filha e seus dois filhos mais velhos. Nos dois anos seguintes, o grupo doméstico de Daniela ganha mais dois membros, Matheus e Marina, e se muda para um conjunto habitacional em Costa Barros, um bairro na Zona Norte do Rio de Janeiro inserido em um projeto municipal de reassentamento. Com seus dois filhos mais velhos trabalhando e sua filha podendo ajudar com as tarefas domésticas e com os cuidados dos dois irmãos menores, Daniela vive um período de maior estabilidade.

Cerca de dois anos após a mudança, seu marido descobre que é HIV positivo, adoece e falece pouco tempo depois. Com os dois filhos pequenos, sem poder contar com a ajuda financeira do marido, já falecido, Daniela tem que aumentar sua carga de trabalho e recorre à ajuda de seus parentes e filhos. O segundo filho havia se mudado com sua companheira para uma casa ao lado da sua. A filha mais velha, já casada na época, fica cuidando de Marina para a mãe trabalhar. A irmã, depois de muita insistência da mãe, assume, por um curto período de tempo, o cuidado de Matheus.

O trabalho de manutenção da família - e as mudanças de casa implicadas -, no caso de Daniela, envolve uma organização doméstica e interdoméstica feita através das tensões e negociações que dizem respeito às relações familiares. Quando não é possível ter uma casa comprada, cedida ou alugada, formando uma "família independente" para a realização das diferentes atribuições do homem e da mulher, a malha familiar se mantém na cena cotidiana, criando uma situação sempre concebida como provisória (SARTI, 2009). A organização do grupo doméstico de Daniela por diversas vezes extrapola os limites de sua residência e se concretiza nessa relação interdoméstica: seja, por exemplo, quando decide juntar-se à sua mãe para assegurar a manutenção da renda familiar e o cuidado dos filhos; ou quando, no curto período de separação, permanece com sua filha morando com a mãe e o irmão, enquanto seu marido e dois filhos vão para outra casa; ou ainda quando, após o falecimento do marido, seus filhos (mais velhos e mais novos) se dispersam, mantendo-se, todavia - filhos e familiares -, partes ativas na organização do grupo. 
A prática da circulação de crianças - utilizada no exemplo acima e presente nos casos apresentados a seguir -, compreendida como "toda transação pela qual a responsabilidade de uma criança é transferida de um adulto para outro" (FONSECA, 1995, p. 116), é especialmente relevante para a compreensão dos fluxos familiares nas classes populares. A participação das mulheres em atividades remuneradas, geradoras de renda para a economia doméstica, para usar o mesmo exemplo de Woortman, depende em grande parte da possibilidade de contar com parentes para cuidarem da criança (seja de forma permanente ou intermitente). Do ponto de vista das crianças, questiona a autora, "a qual unidade doméstica pertencem: àquela onde passam o dia ou àquela onde passam a noite?” (WOORTMAN, 1987, p. 64). Da mesma forma, órfãos, doentes e inválidos são amparados pelas famílias como um gesto de solidariedade aos membros assolados pelo infortúnio. Sendo assim, é imprescindível entender que o grupo doméstico é, em si, um processo em constante formação, que permite a realização de diferentes soluções contingentes relacionadas à qualidade de vida de uma situação de classe, e aos desafios impostos pela trajetória do grupo doméstico (WOORTMANN, 1987).
A prática de transferência de cuidado pode ocorrer entre parentes e amigos, podendo assumir um caráter mais permanente - isto é, até que os filhos se tornem independentes - ou por curtos períodos (DUARTE, 2008). Tal transferência pode acontecer tanto em sua totalidade, quando a criança fica sob a responsabilidade de outro adulto podendo, ocasionalmente, levar a um processo legal de adoção - quanto de forma parcial, quando a criança passa parte da semana (os dias de escola, por exemplo) ou parte do dia (durante as horas de trabalho da mãe) sob os cuidados de outrem; ou ainda quando permanece por períodos de mais necessidade (seja pela instabilidade financeira e de moradia ou por demandarem um cuidado específico). Ademais, parentes podem ser importantes alternativas para as eventuais situações imprevistas e urgentes (como quando um filho fica doente, quando não há aula etc.), assim como nas situações de lazer (viagens de férias escolares, feriados, finais de semana etc.).

Em 2000, três anos após a morte do primeiro companheiro, Daniela casa-se com Pedro. Ao casar-se novamente, Daniela se muda com seus dois filhos pequenos para a casa do atual marido, localizada em Nova Aurora, bairro do município de Belford Roxo. Após cerca de 
três anos morando nesta casa, Daniela convence o marido de se mudar para sua antiga casa, no conjunto habitacional em Costa Barros, mais bem localizada e com infraestrutura urbana. Daniela, grávida de seu sexto filho, Simão, primeiro de sua nova união, se muda para a casa em que morou com o seu primeiro marido.

Daniela, ao casar-se novamente, consegue cuidar dos seus filhos mais novos, que antes estavam sob os cuidados de sua irmã e sua filha mais velha. Entretanto, ao mesmo tempo em que o recasamento possibilitou essa reaglutinação dos filhos pequenos, ele a afasta dos filhos mais velhos, que não aprovam a nova relação. A situação de desconforto com os filhos mais velhos chega a um ponto insustentável e o casal vai morar na Ocupação Quilombo das Guerreiras com os três filhos menores de Daniela. As disputas internas entre os filhos e o marido impossibilitam seu projeto de formação de um grupo interdoméstico. Ela só consegue compor uma união conjugal, quando ela afrouxa seus laços com o agrupamento doméstico anterior. O deslocamento, neste caso, é um elemento definidor da formação de seu novo grupo doméstico.

A ocupação trouxe, nesse sentido, uma solução, ao facilitar a formação de grupos domésticos independentes. Em minhas entrevistas, ao perguntar sobre os motivos que as levaram a vir morar em uma ocupação - para além das justificativas relacionadas à facilidade de morar no centro da cidade, ao fato de não precisarem pagar aluguel e ao fato de morarem em um lugar seguro -, muitas mulheres responderam que estavam ali por uma decisão do companheiro: "Vim para perto do meu marido, [ele] já tinha vindo pra cá desde o começo"; "Não sou do Rio. Casei e vim morar com o meu marido"; "Meu marido que decidiu vir morar aqui. Ele achou que ia ser bom e eu vim". Além disso, a estabilidade de moradia atrai a vinda de filhos, sobrinhos, netos, parentes e amigos, possibilitando para muitas famílias uma (re)aglutinação do grupo doméstico.

$\mathrm{Na}$ ocupação, Daniela consegue estabelecer um grupo doméstico independente, mesmo que isso tenha lhe custado sua relação mais cotidiana com os filhos mais velhos. A ida para a ocupação, apesar de arrefecer, não cessa os conflitos com os filhos mais velhos, principalmente através de Matheus, que começa a confrontar o padrasto. Matheus vai, então, morar com o irmão mais velho. Suas visitas, que no início eram bastante frequentes, tornam-se cada vez mais raras.

Ainda assim, há um trabalho constante por parte de Daniela para 
reaver as relações com os filhos a partir das renegociações familiares (com os filhos e com o atual marido). Com o despejo da ocupação, em fevereiro de 2014, ela, o marido e o filho do casal vão morar na antiga casa de Daniela, perto da família dela, em Costa Barros. Com a proximidade de sua filha mais velha e de seus filhos e suas noras, Daniela retoma os laços com seus parentes: refaz amizades com as vizinhas, cuida dos netos e planeja trabalhar na pizzaria que o filho mais velho acabara de montar.

Porém, a distância do local de trabalho de Pedro, um senhor de mais de 60 anos, o incômodo de ter sua filha morando na casa de outra pessoa, e a situação desconfortável de "morar de favor" (ainda que a casa seja, por direito, de Daniela), principalmente após tantos conflitos no passado, faz com que Pedro recorra, mais uma vez, ao movimento de luta por moradia para buscar uma solução, e recebe a autorização para residir no terreno destinado ao projeto de moradia popular onde será construído o conjunto habitacional. Pedro, Daniela e Simão voltam para a área central da cidade, em agosto do mesmo ano, facilitando o acesso ao trabalho de Pedro e às reuniões mensais do Projeto Quilombo da Gamboa.

O exemplo de Daniela é ilustrativo de como a família de classe popular, por mais que constitua, quanto à unidade residencial, uma família conjugal isolada, não prescinde dos laços referentes à família em sentido extenso. Tais laços, bastante úteis e frequentemente acionados como uma rede de suporte, de trocas e cooperação, também podem originar conflitos e tensões, levando a distanciamentos afetivos-espaciais para que os laços de aliança do casal sejam mantidos. De todo modo, o exemplo de Daniela se refere a duas relações conjugais relativamente estáveis. Mesmo que recorra aos familiares para moradia ou para ajuda com o cuidado das crianças, o grupo doméstico de Daniela é marcado pela presença quase constante de um cônjuge. Ao mesmo tempo, as relações interdomésticas que estabelece, se dão no interior de sua própria família no sentido extenso. A moradia de sua mãe serve como um ponto de apoio quando, por motivos diversos, o grupo doméstico de Daniela se vê ameaçado. Já no caso que veremos a seguir, o caso de Ilana, a família extensa matrilateral não oferece a mesma estabilidade e segurança, e a vida de Ilana é marcada por uniões sucessivas e instáveis e, portanto, por uma presença menos constante de um companheiro. Mesmo assim, o projeto de formar uma família conjugal isolada se manifesta continuamente em sua trajetória e sua 
frustração leva Ilana a frequentes mudanças de casa e a outros desafios na manutenção de seu grupo doméstico.

Ilana e a presença masculina nas "famílias de mulheres"

Diferentemente de Daniela, que é natural do Rio de Janeiro, Ilana, de 42 anos, nasceu em Novo Cruzeiro, Minas Gerais, mas, como ela diz, foi "criada em Brasília”. Sua infância é descrita por deslocamentos forçados para trabalhar na casa de terceiros. Aos sete anos de idade fora enviada com a irmã (um ano mais velha) para trabalhar na casa dos tios em Brasília. Ambas dividiam o trabalho doméstico e, em contrapartida, suas tias, além de lhes prover alimento, cuidado e educação, enviavam uma "ajuda" para a mãe e seus irmãos. Quando finalmente retorna para Minas Gerais, sua tia a envia novamente para trabalhar como doméstica em uma casa de família, desta vez em São Paulo. Através de uma atravessadora, que organizava o esquema do tráfico e exploração de menores, Ilana passa a morar e trabalhar no bairro do Butantã.

Pouco tempo depois, Ilana retorna, mais uma vez, para Minas Gerais. Após se envolver em um relacionamento abusivo (sobre o qual não gosta de conversar), Ilana, levando o documento de identidade da irmã mais velha, foge com uma amiga para o Rio de Janeiro antes de completar doze anos. Ilana mora atualmente no Rio de Janeiro com sete dos seus oito filhos, formando uma unidade residencial pautada na díade materna (mãe-filhos). Entretanto, na medida em que Ilana me contava sobre seu passado, ela enunciava os homens que foram importantes em sua trajetória, e que, de formas diferentes, ajudaram-na a superar as peripécias da vida. As relações de apoio mútuo por ela estabelecidas, uma vez que não possui vínculos familiares consanguíneos (ao menos no sentido estrito) no Rio de Janeiro, foram construídas na localidade e na conjugalidade, pautadas na busca pelo sustento e proteção masculinos.

Woortmann (1987) afirma que a organização do grupo doméstico e seu funcionamento devem ser pensados abarcando as relações de parentesco mais amplas (ou genéricas), mas o grupo doméstico é, não obstante, um ponto focal importante para o entendimento da ideologia de papéis sexuais. Quando se considera o grupo doméstico desde um ponto de vista estático, cria-se uma tipologia de unidades residenciais. Contudo, Woortmann insiste que, na realidade, o que existe é um modelo flexível que permite a realização de 
diferentes soluções contingentes, no qual diferentes unidades residenciais representam momentos distintos num movimento dinâmico. Para a autora, a unidade "nuclear" ou "elementar" deste sistema de parentesco não é a família conjugal, mas a unidade ou grupo doméstico formado por mãe-filhos. Assim, segundo a autora, o parentesco matrilateral, mais que o parentesco em geral, seria o princípio organizador dominante na formação do padrão de arranjos residenciais.

No nosso caso, a categoria residencial "mãe sozinha com filhos" contabilizava quase $30 \%$ das famílias que moravam na Ocupação Quilombo das Guerreiras - o que não surpreende se comparado às estatísticas e aos estudos sobre famílias nas classes populares. Todavia, um olhar mais aprofundado revela que esses números podem ser enganadores, uma vez que encobrem a presença masculina marcante nessas “famílias de mulheres" (FONSECA, 2004). O estudo da dinâmica do grupo doméstico seria, então, uma maneira de testar a importância relativa de homens e mulheres nas teias de relações.

Segundo Fonseca, as tipologias baseadas na unidade residencial, precisamente por partirem de uma imagem estática do grupo doméstico, podem gerar análises apressadas da "matrifocalidade" nas classes populares urbanas, uma vez que a categoria "mãe sozinha com filhos" pode encobrir dinâmicas familiares inteiramente diferentes (FONSECA, 2004). Na pressa de achar novos casos "matrifocais", pesquisadores tendem a "queimar etapas". A alta proporção de unidades domésticas na categoria "mãe sozinha com filhos", segundo a autora, pode ser ocasionada por um sistema onde predomina, como no Caribe, um núcleo doméstico de consanguíneos matrilaterais relativamente estável e autossuficiente, onde a presença esporádica de companheiros sexuais não modifica a organização fundamental do grupo. Entretanto, na realidade encontrada entre os sujeitos de seu trabalho, Fonseca observa que essas unidades domésticas de mães com filhos participam de um sistema no qual predomina a unidade conjugal patriarcal, ou seja, representam uma fase transitória entre duas uniões conjugais. Suas observações sobre as diversas atividades familiares na comunidade por ela estudada - ao contrário dos resultados esperados conforme o modelo matrifocal evidenciam que os laços homem/homem ou homem/mulher têm tanta importância quanto os laços mulher/mulher. 
Para compreender os papeis sexuais na organização do grupo doméstico nas classes populares, Tania Salem (2006), em seu artigo “Tensões entre gêneros nas classes populares: uma discussão com o paradigma holista”, estabelece as diferenças entre duas formas de abordar estes papeis: os paradigmas holista (ou hierárquico) e individualista, este último operando como cosmologia das classes médias. Essas diferenças se especificam na forma e nos significados que imputam ao vínculo entre os gêneros e a sexualidade. Para o individualismo, a segmentação do sexo se produz na conjugalidade e na sexualidade, e representam a essência constitutiva da personalidade. Já no paradigma holista, o sexo aparece englobado nas relações de família (dimensão da reciprocidade).

Salem (2006) discute as duas premissas do paradigma holista: a de que é na família e na localidade, mais que no sexo, que se armam as identidades; e a de que a relação entre essas identidades se funda em sua reciprocidade. Os homens e as mulheres das classes populares, explica Salem, imputam significados distintos às sexualidades. As mulheres estariam voltadas para a rede familiar, já os homens formam diversas famílias, e seu comportamento estaria atravessado por um componente de impermanência.
Enquanto as mulheres percebem a esfera do sexual dentro da ideia de família havendo uma homologia entre o modelo holista e o ethos feminino -, os homens parecem se colocar do lado do eixo individualista, aspecto que é comumente interpretado como uma "contaminação" do homem de classe popular ou uma "modernização parcial das classes populares". Salem sustenta, todavia, que existem diferenças perceptíveis a partir de duas representações masculinas: em primeiro lugar, a perspectiva do "sexo pulsional”, quer dizer, a percepção de que são governados pela natureza do sexo, que contrasta com o voluntarismo do modelo individualista; e, em segundo lugar, a lógica hierárquica entre os gêneros, que afirma que eles têm naturezas e vocações díspares.

Da mesma forma, Duarte (1986) observa que a chamada "matrifocalidade", tão frequentemente encontrada nesses segmentos sociais (e designadas pelo senso comum como "mães solteiras"), não obedece à adoção de uma perspectiva igualitarista individualizante, mas decorre da articulação entre o predomínio da consanguinidade uterina com a exacerbação da lógica de exterioridade do masculino. Esta articulação, associada a condições de precariedade ou instabilidade 
do trabalho, leva à presença intermitente do homem na unidade doméstica.

As diferenças entre os gêneros apresentam uma tensão estrutural entre o polo feminino e o masculino. Tal processo de tensão e diferenciação entre os sexos confirma as avaliações morais e alimenta os estereótipos de gênero: a impermanência masculina descansa na permanência feminina. Sem embargo, Salem (2006) reafirma que o modelo não tem falências e se conserva pela dependência mútua estimulada por condições estruturais precárias, mas também por qualificações que, na prática, suavizam as tensões. Para Sarti (2009), usar a noção de reciprocidade, como base das relações de gênero, significa entendêlas em termos relacionais. A identidade de gênero não tem uma propriedade substantiva. Ela é definida como uma relação que se baseia numa lógica de reciprocidade. Tal lógica, segundo a autora, confere sentido às relações de gênero e à divisão de espaços masculinos e femininos no mundo social. O desempenho recíproco é o que dá sentido às relações de gênero, tal como estão estruturadas.

O caso de Ilana é ilustrativo das diferentes formas de participação do homem na organização do grupo doméstico. O predomínio da díade materna, mesmo que intercalado por uniões conjugais, não prescinde do papel do homem, seja como provedor, como protetor do grupo, ou como figura de autoridade. Já morando no Rio de Janeiro, Ilana conhece seu segundo companheiro, Cláudio, quando tinha dezoito anos de idade. Juntos, passam a morar em uma casa no Morro Santo Amaro, no bairro do Catete, com seus dois filhos: Silvia e Ian. Ilana descreve o marido como um homem trabalhador e honesto, que não faltava com suas responsabilidades dentro de casa. O relacionamento dura cerca de seis anos. A separação, no entanto, configura uma mudança pequena em seu grupo doméstico, pois continua morando no mesmo lugar. Como seu ex-companheiro trabalhava em embarcações, quase não aparecia em casa, e Ilana, na prática, passa seus dias como mulher solteira, e se envolve em novos relacionamentos amorosos. Cláudio, contudo, segue como principal provedor da família até seu falecimento, cinco anos mais tarde. Mesmo o fato de Ilana engravidar duas vezes, de Tatiana e Carlos - frutos de relações que ela chama de "aventuras" -, não rompe a relação entre Ilana e seu ex-companheiro. As novas gravidezes de Ilana não significam a presença de um novo homem no grupo doméstico, e os pais biológicos não estão sequer na certidão de nascimento dos filhos. Assim, o ex-marido 
de Ilana continua representando a figura do "homem de família". Há, portanto, um distanciamento afetivo, mas também a manutenção da proximidade espacial. O grupo doméstico permanece inalterado, mesmo com a chegada de novos filhos fora do casamento.

Com o falecimento de seu excompanheiro, a situação financeira de Ilana se complica. Ilana e seus filhos continuam morando no Morro Santo Amaro, pagando aluguel, mas agora em uma casa menor e mal localizada. As condições de habitação do grupo doméstico de Ilana só melhoram após ela conhecer seu terceiro marido, com quem terá uma relação de cerca de cinco anos. Contudo, esta relação é marcada, sobretudo, pela impermanência e instabilidade financeira do novo companheiro. Segundo ela, Marcos "não pegava no pesado" e, por isso, Ilana trabalhou durante todo o tempo em que estiveram juntos. Após o nascimento do primeiro filho do casal, a família de Ilana muda-se para o Casarão Pedro Américo, uma ocupação localizada também no Catete.

O curto período em que Ilana morou no Casarão foi marcado por situações de conflito e desgaste com os parentes de Marcos e a vizinhança. O relacionamento conturbado, de idas e vindas, coloca em questão o prestígio de Marcos como "homem de família". A presença intermitente de Marcos, mesmo que assegure, ao menos parcialmente, sua posição no agregado doméstico, desencadeia um processo que configura seu enfraquecimento nas relações de poder no interior do grupo doméstico e entre os vizinhos. $\mathrm{O}$ controle da sexualidade feminina depende do status do homem protetor. Se não há comprometimento da parte masculina, não há, também, quaisquer impeditivos para investidas de novos pretendentes. Do mesmo modo, o status de Ilana como "mulher casada" também é questionado e, assim, sua família perde positividade, assegurada pela presença da figura masculina: suas filhas são alvos de assédio, e ela, de especulações sobre sua vida amorosa.

Seria errôneo imaginar que as classes populares não têm consciência do modelo "ideal” da família conjugal. Existe uma força simbólica nas famílias pobres urbanas que reafirma a autoridade masculina pelo seu papel central de mediador com o mundo externo, e que provê teto, alimento e respeito. Entretanto, embora o homem seja identificado como a figura de autoridade, isso não significa que a mulher seja desprovida de autoridade. A busca da mulher pela união conjugal, como ressalta 
Fonseca, vai muito além da ordem material, motivada por imperativos de sobrevivência. Ao casar, a mulher tem esperança de alcançar não só uma certa segurança material e física, mas também uma satisfação afetiva e um status respeitável para si e sua família.

Segundo Sarti (1989), na perspectiva feminina, o conflito surge quando o homem não cumpre o papel de provedor e pai/marido responsável. O conflito nas relações entre o homem e a mulher é traduzido como desrespeito ao código de reciprocidade. Este configura o principal motivo que pode levar uma mulher a formular sua preferência pela separação, como um mal menor. A impermanência do homem transfere a responsabilidade - sua enquanto "homem de família" - para a mulher, o que reequilibra a relação de forças. As mulheres, por sua vez, apelam para o modelo dominante-ideal para afirmar sua autonomia e dominância.

As situações de conflito e desgaste com os vizinhos e parentes do companheiro fazem com que o casal resolva ir para Minas Gerais, morar junto com a irmã de Ilana. Assim, o casal refunda seu status conjugal, o grupo doméstico reforça seus laços, ganha coesão e se reaproxima da família original de Ilana. Entretanto, sem muitas opções de trabalho, Marcos e Ilana decidem, dois meses depois, retornar ao Rio de Janeiro, em 2006. O casal traz consigo os dois filhos mais jovens, frutos dessa relação, e os outros quatro ficam com a sua irmã em Minas Gerais. Marcos recebe o convite para se tornar morador da ocupação Quilombo das Guerreiras e Ilana vai com ele. Passado mais de um ano de seu retorno ao Rio, Ilana finalmente "manda buscar" seus outros filhos que ficaram em Minas. Em 2008, Ilana tem o terceiro filho com Marcos, ainda morando na ocupação. Entretanto, seu relacionamento termina quando, segundo ela, ele começa a sair com outras mulheres dentro do prédio:

Depois ele começou a me sacanear
aqui dentro, a gente começou a
brigar. Marcos era um cara
maneiro, eu gostava muito dele.
Quando eu soube que ele tava
saindo com homem, com mulher
aqui de dentro... Pô, mulher
arruma na rua, né? Vai arrumar
mulher aqui dentro, onde que a
gente mora, pra ficar todo mundo
rindo da cara da gente? Aí eu não
quis mais.

A situação que emerge na trajetória de Ilana frustra mais uma vez seu projeto familiar, mas, desta vez, seus 
desdobramentos são outros. Desde cedo, as situações de conflito conjugal, separação ou falecimento do companheiro, relatadas por Ilana, obrigaram-na a deslocar-se para concretizar novos projetos de vida. Entretanto, a Ocupação Quilombo das Guerreiras representou, para o grupo doméstico de Ilana, uma estabilidade de moradia. A separação de Marcos, após diversas tentativas de consolidar a união conjugal, não representa uma mudança brusca em sua vida. Ao consolidar, ao menos temporariamente, uma moradia mais estável, sem que precise de um companheiro para ajudar com o aluguel, Ilana ganha força e poder de escolha frente às futuras relações.

Após o rompimento, Marcos sai da ocupação e ela começa a se relacionar com outro morador. Como Danilo já residia na ocupação quando começou sua relação com Ilana, eles moravam em unidades residenciais distintas. Com isso, conseguiam manter a privacidade do casal, ao mesmo tempo em que Ilana estava perto de seus filhos. Pouco tempo depois, a relação se consolida com o nascimento de uma filha do casal. Ilana, neste momento, consegue conciliar sua união conjugal com uma outra residência pautada na díade materna. Ilana passa boa parte de seu tempo na casa de seu companheiro, arruma as coisas, cozinha e, quando quer momentos a sós com Danilo, deixa a filha mais nova sob os cuidados de Silvia (sua filha mais velha). Seu grupo doméstico, portanto, engloba as duas unidades de moradia.

No entanto, após uma série de conflitos com outros ocupantes, e muitas advertências por parte do Coletivo de moradores, Danilo acaba expulso da ocupação. Mais uma vez, Ilana permanece na ocupação, enquanto seu companheiro se muda para a Ilha do Governador. Mesmo com o marido distante, Ilana busca manter a coesão do grupo doméstico de duas residências, e passa a frequentar a casa de Danilo (levando a filha do casal) durante os finais de semana, e deixando os outros filhos sob os cuidados de Silvia. Porém, pouco tempo depois, eles rompem o relacionamento.

Os sucessivos relacionamentos de Ilana indicam seu fracasso em constituir uma união conjugal estável. Contudo, a impermanência masculina não deve ser pensada como uma ausência ou uma nãopresença do masculino na organização dos grupos domésticos. As mulheres "sozinhas", sobretudo as mais jovens, muitas vezes contam com um homem que assume publicamente o papel de defensor do grupo doméstico. Assim, não é a residência conjugal que é predominante, 
mas a relação ou, ao menos, o status conjugal. As mulheres que não possuem essa figura masculina que cumpra o papel delegado ao "homem de família", tendem a engajar-se "no mercado matrimonial à procura de um tal protetor" (FONSECA, 2004, p. 84). Entretanto, isso não significa que outras figuras masculinas, que podem variar radicalmente ao longo da vida da mulher, não possam também assumir alguns desses papéis (FONSECA, 2004).

O termo "família chefiada por mulher", como observa Fonseca (1987), tem sido empregado para designar unidades domésticas de mulheres sem marido ou, quando há marido, aquelas em que o número de consanguíneos matrilineares é maior ou aquelas em que a renda da mulher supera a do homem. Entretanto, como argumenta a autora, reduzir a presença masculina ao puramente econômico seria um erro, visto que o simples fato das famílias serem chefiadas por mulheres, não impede que a figura masculina seja evocada para reestabelecer a honra da família perante os vizinhos ou para fortalecer a hierarquia doméstica.

Uma figura masculina importante nos relatos de Ilana, por exemplo, é seu compadre Guilherme. Ilana conhece o amigo pouco tempo depois de chegar ao Rio de Janeiro e afirma que foi com a ajuda dele que conseguiu construir, mesmo tão jovem, uma vida na grande cidade. Ao me contar sobre Guilherme, Ilana faz questão de ressaltar, diversas vezes, a relação de cuidado que ele tinha para com ela, afastando possíveis mal entendidos. Conta também que ele tornou-se um grande amigo de seu primeiro marido e que batizou o primeiro filho dela, destacando, mais uma vez, a relação de respeito entre os dois.

$$
\begin{aligned}
& \text { O Guilherme. O padrinho do Ian. } \\
& \text { Pode dizer que foi ele que me } \\
& \text { criou. Eu vim pro Rio eu era 'de } \\
& \text { menor'. Eu tinha onze anos. Eu } \\
& \text { vim com o registro da minha } \\
& \text { irmã mais velha, fugida [...] Vim } \\
& \text { direto trabalhar na casa pra } \\
& \text { cuidar de duas meninas, levar pra } \\
& \text { escola. Ai quando eu fiz treze } \\
& \text { anos eu conheci o Guilherme. Eu } \\
& \text { gosto muito dele. Ele era amigão } \\
& \text { do pai da Silvia. }
\end{aligned}
$$

A participação de Guilherme no arranjo doméstico de Ilana se reestabelece, pouco mais de um ano após se separar de Marcos, quando seu filho Ian começa a se envolver em pequenas confusões na Ocupação Quilombo das Guerreiras. Silvia - que é responsável por grande parte das tarefas domésticas que envolvem os 
irmãos menores, desde acordá-los para ir à escola, até alimentá-los e cuidar da sua higiene pessoal -, com apenas dois anos de diferença do irmão, começa a ter sua autoridade contestada pelo adolescente. Ao acionar seu amigo de longa data, e padrinho do filho, Ilana busca o auxílio daquele que ainda consegue manter autoridade sobre ele. Com o objetivo de "educá-lo" - controlando seus horários e levando o adolescente para ajudar em seu trabalho -, Guilherme se responsabiliza, ao menos em parte, pelo cuidado de Ian.

Testemunhei, diversas vezes, mães pedindo para que vizinhos (homens) levassem seus filhos para ajudar no trabalho: "Ele tá demais. Tá aprontando muito. Tá me fazendo passar vergonha. Pedi para levar ele, assim sei que tem alguém cuidando, pra ver se cria juízo". Para as meninas, como o trabalho doméstico já faz parte dos seus afazeres diários, a solução é tentar encerrá-las em casa. Ilana, por exemplo, após ficar sabendo que sua filha estava "matando aula" para se encontrar com um jovem, quebra o celular de Tatiana, para que ela não possa mais se comunicar com ninguém. Sabendo que os encontros entre os dois continuavam, Ilana chama seu filho Ian para "dar uma prensa nela": "Se eles não respeitam a gente [Ilana e Sílvia], eles vão ter que respeitar ele”. Ilana repete o que fez com o filho mais velho durante sua adolescência, dessa vez pedindo para que ele, agora adulto, assuma a responsabilidade como primogênito e volte a morar em sua casa, garantindo a respeitabilidade da família.

A mulher, ressalta Fonseca (2004), não é exatamente coagida a aceitar um marido ou amante. Durante os anos reprodutivos da mulher, ela é cúmplice de um pacto conjugal no qual espera conseguir o status prestigioso de "mulher casada”. Porém, com o avançar da idade, essas aspirações não permanecem por completo. A mulher, chegando numa idade mais avançada, pode, afinal, exercer sua liberdade de escolha sobre a companhia masculina e "não é raro que, em vez do marido, ela escolha o filho" (FONSECA, 2004). As tensões conjugais são levadas para os filhos homens, sobretudo o primogênito, que diante da ausência do seu pai, adquire o compromisso moral de apoiar e ajudar a sua mãe. (SALEM, 2006).

A predominância da família de origem sobre a de constituição para os filhos homens, conforma uma estratégia de reparação nesse modelo de relacionamento e tensão entre os gêneros. Assim, os homens são, ao mesmo tempo, individuados em relação a suas parceiras e não em relação às suas mães. A submissão 
da jovem ao marido, que possui maior peso, inclusive, na escolha da residência, não é incompatível com a eventual ascendência da mulher mais velha, em grande parte, graças à sua relação privilegiada com filhos adolescentes e adultos (FONSECA, 2004). Seja através dos filhos mais velhos, dos irmãos, dos tios, dos padrinhos, dos compadres, dos vizinhos, dos companheiros ou dos excompanheiros, os homens fazem parte dessa malha que compõe as relações familiares e domésticas.

Mercedes: as relações mulher-mulher $e$ as "coisas da família"

Enquanto o caso de Daniela ilustra uma situação relativamente estável em relação à participação do cônjuge na organização do grupo doméstico, tendo também sua mãe, irmã, filha e filhos cumprido um papel ativo na organização do grupo doméstico; no exemplo de Ilana, as relações pautadas na reciprocidade são cumpridas, em grande parte, pela figura masculina (seja o cônjuge, o "compadre" ou o filho mais velho) que, mesmo de forma oscilante, assume um importante papel na organização e manutenção do grupo doméstico. No caso que veremos a seguir, todavia, embora compartilhe desta intermitência do papel masculino, buscaremos ressaltar as relações mulhermulher, seja como irmã, avó, sogra ou prima. Mercedes, assim como as demais, persegue o projeto de constituir uma família conjugal isolada, e por isto abandona suas coisas e sua estabilidade financeira. As situações que emergem para frustrar suas expectativas, porém, fazem com que tenha que repetidamente recorrer à sua família no sentido extenso. E, como veremos, são as mulheres que atendem seu chamado.

Cláudia Fonseca, inspirada nos trabalhos de K. Sachs, argumenta que a oposição entre consanguinidade e aliança reveste-se de uma importância particular no estudo do poder feminino. Segundo ela, Sachs sugere que os antropólogos, ao privilegiarem a perspectiva de "mulhercomo-esposa" em vez da "mulher-comoirmã”, têm alimentado uma imagem exagerada da inferioridade (universal) feminina. Nesse sentido, cabe nos voltarmos para o exemplo de Mercedes e sua família extensa, dando destaque ao papel que as mulheres exercem na gestão de seu grupo doméstico.

Empregada doméstica, Mercedes é maranhense, 44 anos de idade, e mãe de três filhos: Djavan, que tem 28 anos e também nasceu no Maranhão; Daniel, filho adotivo de Mercedes, filho biológico de sua irmã, nasceu no Rio de Janeiro e 
tem 16 anos; e, por último, Denis, seu filho mais novo, de 13 anos, que nasceu no Rio Grande do Sul. Mercedes nasceu em Raposa, no Maranhão. Seu pai deixou sua mãe quando ainda estava grávida e sua mãe a confiou aos cuidados de sua avó quando ela tinha sete anos, para vir procurar emprego no Rio de Janeiro.

No entanto, pouco depois de ver sua mãe partir, aos nove anos, Mercedes deixa a casa da avó (em Raposa) para trabalhar na casa de uma família em São Luís do Maranhão. Com a promessa de ser alimentada, vestida, bem cuidada e educada, sua função é, basicamente, cuidar dos filhos da patroa em troca de seu sustento. Após dois anos, a mãe de Mercedes a leva para o Rio de Janeiro, mas a deixa sob os cuidados de outra família. Aos 11 anos de idade, Mercedes já começava sua segunda experiência de trabalho e, com 14 anos, ainda no Rio de janeiro, quando vai morar com um casal, sua terceira. Dos nove aos quatorze anos de idade, sua vida é definida por sua mãe e sua avó, e marcada por sucessivas mudanças de "tutoras", que a abrigavam e a sustentavam em troca de seus serviços.

Mercedes engravidou de seu primeiro filho com 15 anos, pouco tempo depois de voltar para casa de sua avó materna em sua cidade natal. $\mathrm{O}$ jovem de quem engravidou não tem qualquer relação com o filho e Mercedes conta com a avó materna para cuidar de Djavan. Apesar de ser "apenas uma criança", como ela diz, Mercedes consegue um trabalho tecendo redes de pesca de nylon para ajudar sua avó com a renda da casa. Porém, sem renda suficiente para sustentar a família, ela encontra no relacionamento com um homem mais velho, dono de uma embarcação lagosteira, um meio de prover uma vida mais confortável para ela e sua família. $\mathrm{Na}$ época, ela tinha dezessete anos de idade, e ele, quarenta e oito. Ainda casado com outra mulher, ele "monta uma casa" para ela morar, e vai visitá-la com frequência. Mercedes se muda para a nova moradia e deixa o filho com sua avó. Com o dinheiro que ele provia, Mercedes conseguia sustentar a si, a avó e o filho. A única condição que ele impunha era que seus familiares não morassem com ela. Mercedes muda de casa, mas não forma um grupo doméstico independente com o amante, uma vez que não reformula as relações de interdependência com sua avó. Sem o apoio do pai de seu filho, ou mesmo de seu pai e seus irmãos, que também moravam em Raposa, Mercedes encontra neste relacionamento os meios para prover as necessidades financeiras do grupo doméstico para que sua avó possa 
se dedicar exclusivamente às tarefas relacionadas à casa e à criação de seu filho.

Após o fim do relacionamento, Mercedes decide voltar para o Rio de Janeiro, deixando seu filho com a avó, vindo trabalhar como doméstica, repetindo a mesma sina de sua mãe. Cerca de dois anos depois, Mercedes junta dinheiro e traz seu filho, com seis anos na época, para morar com ela. Nos próximos quatro anos, já com uma situação financeira estabilizada, ela adota o filho de sua irmã mais nova e compra a passagem da avó para que ela venha residir em sua casa. Mercedes pôde, assim, não apenas reaglutinar seu grupo doméstico, antes espacialmente disperso, mas também incorporar um novo membro que participava de um outro grupo doméstico. Mercedes me conta de alguns namorados que teve durante o período, porém, reafirma constantemente seu orgulho de, sozinha, ter "melhorado de vida" (SARTI, 2009).

No Rio de Janeiro, Mercedes conhece seu primeiro marido. Eles se casam já com a pretensão de se mudarem para o Rio Grande do Sul. Neste momento, Mercedes se afasta de amigos e parentes, principalmente de sua mãe, sua irmã e suas primas, para formar um grupo doméstico independente com o marido e os dois filhos. Seu casamento não apenas marca uma mudança de casa e de cidade, mas de status. Mercedes é, agora, uma mulher casada e vai, acompanhando seu marido, para perto da família dele.

O novo projeto familiar, de uma vida nova, é marcado pela compra de novas coisas e a doação das coisas antigas. Certa de que viveria um "conto de fadas" na cidade natal de seu companheiro, ela doa grande parte de seus pertences para sua prima e para sua irmã, e segue seu sonho levando com ela seus dois filhos (a avó já havia falecido). Quando chega ao Rio Grande do Sul, monta uma "casa nova" com todos aqueles elementos que para ela eram caros na constituição de seu novo lar: mobília nova, fotos antigas, alguns pertences que ela considerava de valor (como o vídeo cassete), seus filhos e seu companheiro: "Mobilhei minha casa, com tudo do bom e do melhor, pago tudo à vista, aquela coisa toda, né? Assim, um sonho, um conto de fadas".

A geografia da família não pode prescindir do estudo das "coisas da família”, não somente porque constituem objetos de relevância simbólica (como partes importantes dos processos de identificação, status social e memória), ou porque demandam cuidado e manutenção, mas também porque possuem um papel ativo nas mediações das relações entre os integrantes do grupo doméstico e de suas 
malhas familiares mais amplas. Portanto, as coisas não compõem o pano de fundo de um determinado contexto, elas se associam a práticas e a outras coisas, e participam ativamente do desenrolar das circunstâncias. Como afirma Latour (2005), as coisas também são capazes de modificar uma dada situação: autorizando, permitindo, aproximando, distanciando, incentivando, sugerindo, impedindo $\mathrm{e}$ proibindo. Segundo Jakob von Uexküll, “[c]omo a aranha tece seus segmentos, cada sujeito tece suas relações com determinados caracteres das coisas em seu entorno, e entrelaçam elas em uma teia firme que são suportes de sua existência"(1957, apud INGOLD, 2012: 14).

A casa, por exemplo, não é somente a estrutura que abriga a família, visto que a estrutura, por si só, sem ser habitada, não é nada a não ser uma abstração, pois o mero fato de existir a coloca sob os efeitos do clima e da ação de seres vivos. Toda construção é uma malha formada por linhas de vida - de coisas e pessoas - em movimento. Bacherlard (1969), baseando-se nos escritos da psicóloga Françoise Minkowska, argumenta que uma casa viva não é realmente "imóvel". Ela integra movimentos particulares. Assim, o autor diferencia aquilo que seria apenas a "casa- construção" daquilo que seria a "casahabitação", englobando o movimento, ora convidativo e ora restritivo ou proibitivo, de fluxos que chegam e que partem. Ginsberg (1999), como Ingold, argumenta que "os seres humanos são homemakers". Segundo ele,

Nós fazemos os nossos lares. Não necessariamente ao construí-los, embora algumas pessoas o façam. Nós construímos a concha íntima de nossas vidas ao organizar e mobiliar o espaço em que vivemos. Como nós funcionamos como pessoa está ligado a como nos construímos a nós mesmos em casa. Precisamos de tempo para transformar a nossa moradia em um lar [...] A nossa residência é o lugar onde vivemos, mas o nosso lar é o modo como vivemos (GINSBERG, 1999, p. 31).

Para fazer de uma casa qualquer, a sua casa, é preciso uma reunião de pessoas e coisas. Coisas que dão funcionalidade a casa, coisas que são sentimentais e coisas que são ambas, sentimentais e funcionais. Uma casa jamais é a casa de alguém ou de uma família sem as coisas que a permitem habitar. Como sinaliza Marcelin (1999), a casa não é somente um bem, um objeto, mas uma prática, uma construção estratégica na produção da domesticidade. 
As coisas carregam memórias (como fotos ou objetos herdados de familiares), simbolizam conquistas, entretêm, distraem, relaxam, ajudam a conseguir um emprego (como um computador), causam orgulho e vergonha. As coisas também medeiam relações, aproximam e afastam. Além disso, coisas compram ou podem ser trocadas por outras coisas.

$\mathrm{O}$ orgulho de ter montado a casa "com tudo do bom e do melhor", no entanto, dura pouco. Com um marido “irresponsável", que "gastava o dinheiro na rua”, Mercedes começa a ver seu sonho virar pesadelo. As coisas que Mercedes tinha comprado para nova casa começam a ser vendidas para arcar com os custos básicos como o aluguel e a alimentação; nem os colchões ela consegue manter. $\mathrm{O}$ "lar idealizado" de Mercedes foi se desmantelando aos poucos, juntamente com seu projeto familiar.

Por isso que eu tenho trauma de faltar as coisas dentro de casa. Fiquei com esse trauma. Duas coisas que fiquei com trauma: de dormir no chão, porque teve uma época que eu tive que dormir no chão com os meus filhos, porque en tive que vender tudo, até os colchões para comprar comida pra eles; e faltar comida dentro de casa.
Durante os seis anos em que Mercedes morou no Rio Grande do Sul, passou por quatro cidades diferentes, deixando para trás, a cada mudança, dívidas com os locatários. Seu companheiro, então, decide ir para Porto Alegre em busca de trabalho, porém, não entra mais em contato com a esposa. Mercedes e os três filhos moravam, na época, em uma casa que pertencia à sua sogra. Ela, uma pastora, residia na igreja e ajudava Mercedes com as doações de seus membros. Com o marido em Porto Alegre, sem qualquer notícia, longe dos seus familiares e dependendo da sogra para sustentar a casa, Mercedes decide voltar para o Rio de Janeiro. Para conseguir retornar, Mercedes vai até o Conselho Tutelar acusando o companheiro de abandono de lar. As fotos do casamento que já foram vetores de lembranças e sentimentos agradáveis, são rasgadas e jogadas do lixo. O retorno ao Rio de Janeiro, levando em suas mãos o documento que afirma o abandono de seu marido, sela o fracasso do antigo projeto de construir sua vida junto ao seu marido.

Para retornar, Mercedes pede ajuda para sua mãe - que começa a aparecer com mais destaque em sua narrativa a partir deste momento - e para uma prima, que encarrega-se da compra das passagens dela e de seus filhos (além 
de arrumar-lhe um emprego); e para sua outra prima, que oferece um abrigo temporário. Ela vai com os três filhos para casa de sua prima, em São Gonçalo, que morava com o marido e dois filhos, e pouco tempo depois decide alugar uma casa com sua mãe, no morro Santo Amaro, no bairro do Catete.

A transferência de cuidado e gestão das coisas para "quem precisa" mantém o vínculo que Mercedes necessita para voltar ao Rio de Janeiro e reestruturar sua vida. Será justamente a "prima que já tinha ajudado antes" que Mercedes aciona para pedir ajuda. A prima, que na ocasião estava bem empregada, e Mercedes invertem os papéis constantemente negociados entre aquele que deve prestar assistência e aquele que merece receber a ajuda.

Os deslocamentos de Mercedes promovem um movimento constante de entrelaçamentos e desentrelaçamentos, referente à sua relação com as primas, a mãe, a avó e sua sogra. O deslocamento espacial "para perto" propicia a proximidade afetiva e, ao mesmo tempo, é precisamente a expectativa da proximidade afetiva que motiva os deslocamentos. Porém, a distância espacial e afetiva nem sempre caminham lado a lado. A mãe de Mercedes se faz como "presença ausente" em sua infância, porém de decisiva importância nos deslocamentos espaciais de Mercedes quando jovem. Depois de adulta, sua mãe se destaca nos dois momentos em que Mercedes busca retornar ao Rio de Janeiro: o primeiro, quando ela vem do Maranhão para trabalhar e mandar dinheiro para a avó que criava seu filho e, o segundo, quando ela decide sair do Rio Grande do Sul. Essa presença efêmera, que ressurge no avançar da linha-da-vida, comungando projetos e caminhando juntas, poderia aparecer de forma conjuntural por todo o percurso narrado, mas suas trajetórias se tocam, se entrelaçam, depois de tanto tempo andando em direções distintas.

Sua relação com a avó se constrói de maneira diferente. A presença da avó de Mercedes é explícita e permanente. Mercedes atribui à sua avó não só sua própria, mas também a criação de seu primeiro filho em sua tenra infância. $\mathrm{O}$ código de reciprocidade, que pauta as relações familiares, se explicita claramente quando Mercedes traz sua avó para morar com ela. Também emerge quando ela recorre às suas duas primas - que já haviam sido ajudadas por Mercedes anteriormente - para sair do Rio Grande do Sul e voltar para o Rio de Janeiro.

No entanto, a vinda para o Rio de Janeiro envolve também a elaboração e a 
prática de um novo projeto de vida, reestruturado, ao lado de sua mãe, com quem permanece até hoje. É com ela que decide participar do processo de ocupação. Ao visitarem uma ex-cunhada de Mercedes, que morava na Ocupação Chiquinha Gonzaga, ela e sua mãe são avisadas que reuniões de organização para um novo processo de ocupação estavam acontecendo: era o processo para a Ocupação Quilombo das Guerreiras. No final de 2013, quando a situação na ocupação começa a ficar insustentável e o despejo se torna uma ameaça iminente, Mercedes e sua família vão morar em São Cristóvão, em um apartamento alugado. Ela e sua mãe continuam inseridas no projeto Quilombo da Gamboa.

De todo modo, o despejo sofrido pelos moradores coloca as famílias novamente em movimento. Nesse sentido, o deslocamento, principalmente quando forçado, promove, muitas vezes, uma dispersão, não apenas dos membros da família, mas também das "coisas da família” e um esforço subsequente para preservar e reagrupar todos esses elementos que davam forma à família, a casa e à coletividade. A situação de constante instabilidade de moradia, de viver "de casa em casa", exige um trabalho contínuo de manutenção e gestão das coisas e pessoas que integram o grupo doméstico. Ilana, por exemplo, quando deixa com sua irmã (em Minas gerais) seus quatro filhos, deixa também as coisas que reuniu em sua antiga casa, além de pertences pessoais.

As coisas da família possuem um importante papel na constituição, manutenção e rompimento de vínculos familiares. Como afirma Ginsberg (1998), o lar é a transformação do lugar pela vida, destinada a abrir o nosso "eu" ao nosso meio imediato. Ele não é apenas confortável, mas reconfortante. O lar é o nosso lugar especial distinto do resto do mundo, onde nos sentimos bem-vindos, imprescindíveis, seguros e que somos cuidados. E, nesse sentido, a mudança de moradia, assim como pode ser um deslocamento para colocar em prática o processo de construção da "nossa casa", pode representar, também, uma ruptura brusca com um lugar que já havia se tornado parte essencial desse processo. A nova moradia de Mercedes e sua mãe, Dona Aparecida, em São Cristóvão, por ser demasiado pequena, não comporta todas as coisas que tinham no quarto da ocupação. Aparecida decide deixar sua mesa e cadeiras em posse de Adelaide (sua comadre e vizinha na referida ocupação), que tinha acabado de mudar-se para o terreno do Projeto (junto com Daniela e Ilana). Assim, caso conseguisse se mudar 
para uma casa maior, poderia recuperar parte de suas coisas. Como as reuniões do projeto são realizadas no terreno, Aparecida podia conferir mensalmente as condições de sua mesa. Após alguns meses, soube através das vizinhas de Adelaide, que Aparecida tinha decidido pegar sua mesa de volta, inconformada com o pouco cuidado da comadre. O pouco cuidado que Adelaide tem com a mesa coloca em xeque seu merecimento e justifica a decisão de Dona Aparecida em reaver suas coisas. As vizinhas, ao me contarem o conflito, concordam com Dona Aparecida e criticam a falta de cuidado de Adelaide:

Dona Aparecida, ela falou que quer as cadeiras e a mesa de volta. Que ela deu pra Adelaide e tá vendo tudo jogado.

Tudo quebrado. Aí, eu tenho um mó cuidado com as coisas que as pessoas me dão.

O universo familiar e do lar envolve toda uma reprodução econômica que, extrapolando a dimensão monetária, diz respeito a um esforço contínuo de gestão, de partilha de obrigações, produção e consumo de comida e de gerência dos cuidados. O exercício dos cuidados tem uma considerável significância na vida das pessoas, envolvendo um conjunto de casas, pessoas e também coisas, através dos quais as relações de parentesco, vizinhança, coletividade e amizade adquirem sentido. A Antropologia já nos presenteou com as análises sobre como as famílias das classes populares dispõem da prática da circulação de crianças para o compartilhamento da responsabilidade pelo cuidado dos filhos. Da mesma forma, podemos pensar as coisas da casa. Assim como na prática de circulação das crianças, a "circulação das coisas" também é, mesmo que de forma parcial e provisória, uma transferência de cuidado. O compartilhamento da gestão e da manutenção das coisas compõe, nesse sentido, essa malha de relações familiares, tecidas no processo de transformação dos grupos domésticos. Os membros da família e as coisas da "sua casa" não estão, necessariamente, reunidos em uma mesma moradia, podendo esta ser composta por pessoas e coisas participantes de outras famílias e lares.

\section{Pensando a geografia da família}

O geógrafo francês Jean-François Staszak afirma que, no campo da Geografia, “a escassez de trabalho dedicado à vida privada e ao espaço 
doméstico contrasta com a abundância de literatura sobre a vida social e o espaço público” (STASZAK, 2001) - com raras exceções, principalmente vindas da geografia anglo-saxã. Staszak questiona se a disciplina poderia ignorar o lugar onde nós passamos grande parte do tempo, onde dedicamos tanto investimento emocional e financeiro, onde os eventos essenciais de nossa vida social acontecem. A espacialidade familiar e doméstica pode nos ensinar sobre "elementos da sociedade que, em análises de outros tipos de espaços, são mais difíceis de abarcar" (COLLIGNON e STASZAK, 2004, p.5). O trabalho aqui desenvolvido busca justamente advogar por uma abordagem sensível à dimensão espacial em relação ao tema.

Desde a década de 1990, a Geografia tem buscado abarcar o estudo da espacialidade das formas de conhecer, amar e cuidar das pessoas, ou o que Valentine (2008) chamou de "geografias da intimidade", incluindo pesquisas sobre a infância e a juventude (HOLLOWAY e VALENTINE， 2000; KATZ， 2004; AITKEN 2001; SKELTON e VALENTINE, 1998) e sobre as vidas de lésbicas, gays e bissexuais (BELL e VALENTINE, 1995; BROWN, 2000). As chamadas "geografias da sexualidade", por exemplo, desafiaram a natureza assexuada da pesquisa geográfica e a heteronormatividade implícita da disciplina. Com isso, vivenciamos uma mudança profunda na maneira como a Geografia pensa e vê o mundo. Apesar do impacto, estes trabalhos focaram seus esforços em pessoas "desviantes" (queer) e não geraram muito interesse no estudo sobre a heterossexualidade ou as relações heterossexuais (VALENTINE, 2008). Tal negligência pode ser atribuída, em parte, à crítica ao modelo patriarcal tradicional e heteronormativo de "família" (por exemplo, de BELL, 1991; BELL e BINNIE 2000), que tem sido uma base de e inspiração para muitos dos escritos feministas e queers no âmbito da disciplina.

Por isso, Valentine (2008) sugeriu, recentemente, que a família como objeto de estudo permaneceu, na história da Geografia, como uma "presença ausente" (VALENTINE, 2008), servindo de apoio a toda uma série de outras geografias, mas sempre em segundo plano. Entretanto, embora avance de forma significativa ao tentar inserir a Geografia nas discussões das relações familiares - apreendidas como uma gama crescente de relações pessoais que fornecem intimidade, carinho e companheirismo -, Valentine (2008) continua presa a uma concepção relativamente rígida de família, ampliada apenas para além das relações parentais. 
Ao compreender que a espacialidade da família não se esgota em sua unidade residencial, mas a extrapola, podemos apreender uma geografia que integra composições cambiantes de configurações familiares, práticas espaciais de alocação de pessoas e coisas, e papéis sexuais com espacialidades distintas, marcados pelo lugar que ocupam no grupo doméstico e por relações de presença e ausência, de permanência e impermanência. A centralidade e permanência da mulher, ponto fixo do grupo doméstico, não a torna um elemento imóvel, mas uma "gestora" do movimento dos integrantes de seu grupo. As mulheres sem-teto deste trabalho jamais estão desabrigadas, mas nem sempre o abrigo comporta tudo aquilo que pertence à família. Assim, fazem circular pessoas e coisas, dispersam no espaço os integrantes do grupo, mesmo que apenas por um momento, para depois reuni-los novamente sob um mesmo teto, conferindo aquilo que poderíamos chamar de lar.

Famílias e lares se constituem a partir de múltiplas atividades de gestão e cuidados, que não se restringem a uma única casa. Como vimos ao longo do artigo, a tipologia residencial que caracteriza as famílias como "extensa”, "conjugal", "nuclear", "mulher chefe de família”, "mãe com filhos" etc., além de confundir as malhas familiares com a unidade doméstica, pressupõem uma imagem estática da unidade residencial, obscurecendo aspectos fundamentais da organização do grupo doméstico. Nesse sentido, ao compreendermos a família e o grupo doméstico como processos formativos que dizem respeito à realização de diferentes soluções contingentes para sua reprodução, podemos, como afirma Fonseca (2004), entender que as diversas "categorias residenciais" se completam. Investigar como se completam, quando e por que um grupo doméstico se transfere de uma categoria para outra, é enfocar, segundo a autora, o sistema familiar como processo.

As malhas familiares estão imbricadas em relações que extrapolam o grupo doméstico, mas que, ao mesmo tempo, agem diretamente sobre ele. Os papéis desempenhados oscilam juntamente com o ciclo de vida dos membros individuais e do grupo doméstico como um todo, impulsionado, muitas vezes, pela instabilidade do mercado de trabalho, a flexibilidade dos laços conjugais e o código de reciprocidade intrínseco às relações familiares. Tal dinâmica do agrupamento doméstico, mesmo quando se refere a famílias compostas por mãe e filhos, inclui a participação ativa do 
homem (mesmo que intermitente), revelando a existência de laços que perpassam a autoridade parental, assim como os laços entre mulheres (mãe-filha; irmãs, vizinhas etc.) elaborando formas diversas de socialidades.

Sem embargo, a impermanência masculina não é uma ausência do homem no grupo doméstico. O "convívio" é permeado por oscilações de difícil delimitação, podendo existir momentos em que a união conjugal se apresenta de "forma mais plena" (comparado ao modelo de família conjugal), e momentos em que sua forma é mais porosa e, por conseguinte, mais propícia à presença de terceiros (seja a família, os vizinhos, ou um/uma amante). Por isso, as categorias estáticas pouco podem nos revelar sobre a mulher que está "separada por um tempo" do companheiro, ou mesmo aquela que, de formas variadas - através do (ex)companheiro, filho, irmão, compadre etc. - , se favorece da presença masculina.

Da mesma forma, a centralidade da mulher, pautada na permanência feminina em relação ao grupo doméstico, não é estática, não é desprovida de movimento. Trata-se, portanto, de uma "permanência dinâmica”. Nos casos das mulheres semteto desta pesquisa, esta permanência está fortemente marcada por um desafio constante de gestão de seus componentes, desafio este sempre agravado pela instabilidade de emprego e moradia. Tal gestão implica o uso de diferentes estratégias que dependem das malhas familiares e de seus deslocamentos (afastamentos ou aproximações) afetivos, afetivos-espaciais ou espaciais. Tais deslocamentos são acompanhados por reorganizações no grupo doméstico podendo conter um caráter de dispersão ou aglutinação de seus elementos formativos. Portanto, nesse movimento de transformação do grupo doméstico, a mulher não só põe a si mesmo em movimento, como, também, põe em movimento as pessoas e as coisas que fazem parte do grupo doméstico.

Atualmente, os conceitos tradicionais da Geografia, como lugar, região e território estão sendo pensados não mais como espaços fechados e “defensivos" (MASSEY, 1994), constituídos por fronteiras estáveis ou fixas, mas como espaços de fronteiras fluidas, visto que se diferenciam não por meio do isolamento (voltados exclusivamente para o interior), mas sim, por meio de suas conexões. Talvez seja hora da Geografia questionar, também, suas concepções sobre a casa, o lar e a família. Compreender a família não como um resultado de seu isolamento, como correspondente a um espaço físico 
claramente delimitado (como a casa), mas como um produto de múltiplas conexões (materiais e imateriais), como um nó de relações espaciais ou um redemoinho em meio a um fluxo, permite reconceitualizar a família como algo que se forma a partir de relações que se projetam para fora, isto é, para além da suposta coesão da unidade doméstica. Trata-se, portanto, de abandonar uma abordagem que concebe a família como um a priori, para apreendê-la na prática, isto é, como ela se realiza efetiva e concretamente no espaço social. Trata-se, por fim, de reivindicar a família como um conceito geográfico, conceito este que "regionaliza" um espaço íntimo, conecta e articula diversas unidades residenciais, e desenha uma malha complexa e cambiante de relações e vínculos sociais.

\section{NOTAS}

1 Esta pesquisa recebeu apoio financeiro da FAPERJ (E-26/100.299/2010) e da PDSE/CAPES (99999.006000/201402).

Agradeço a Rafael Gonçalves de Almeida pela leitura crítica e revisão deste artigo.

2 Doutora em Geografia - Programa de Pósgraduação em Geografia - PPGG/UFRJ.

3 Uma revisão bibliográfica atenta ao tema pode ser encontrada em trabalhos anteriores, como em MOREIRA, 2013a; 2013b; 2011; 2016.

4. Ver também a coletânea Relative Values (MCKINNON e FRANKLIN, 2001), sendo esta mais assumidamente feminista (FONSECA, 2003).

\section{REFERÊNCIAS BIBLIOGRÁFICAS}

AITKEN, S. (2001): Geographies of young people: the morally contested spaces of identity. London: Routledge.

BACHELARD, Gaston (1969): The Poetics of Space. Boston: Beacon Press.

BELL, D. (1991): "Insignificant others: lesbian and gay geographies”. Area 23, pp. 323-329.

BELL, D.; BINNIE, J. (2000): The sexual citizen: queer politics and beyond. Cambridge, UK: Polity Press.

BELL, D. e VALENTINE, G. (eds) (1995): Mapping desires: geographies of sexualities. London: Routledge.

BINNIE, J. e VALENTINE, G. (1999): Geographies of sexuality: a review of progress. Progress in Human Geography 23, pp. 175-187.

BROWN, M. (2000): Closet space: geographies of metaphor from the body to the globe. London: Routledge

CARSTEN, Janet. (2000): Cultures of relatedness: new approaches to the study of kinship. Cambridge: Cambridge University Press.

COLLIGNON, Béatrice; STASZAK, JeanFrançois (org.) (2004): Espaces domestiques. Construire, habiter, représenter. Paris, Bréal-éditions.

DUARTE, Luiz Fernando Dias (1986): Da vida nervosa (nas classes trabalhadoras urbanas). Rio de Janeiro Jorge Zahar/CNPq.

(1995): "Horizontes do indivíduo e da ética no crepúsculo da família”. In: RIBEIRO, Ivete \& RIBEIRO, Ana Clara Torres (orgs.). Família em processos contemporâneos : inovações culturais na sociedade brasileira. São Paulo: Loyola.

DUARTE, Luiz Fernando Dias; GOMES, Edlaine (2008): Três Famílias. Identidades e Trajetórias Transgeracionais nas Classes Populares. Rio de Janeiro: Editora FGV

DURHAM, Eunice (1973): A caminho da cidade. São Paulo: Perspectiva.

FONSECA, Claudia (1987): Aliados e rivais na família: $O$ conflito entre cosanguíneos. Revista Brasileira de Ciências Sociais, v. 4, n. 2, pp. 88-102. 
(1995): Amor e Família: vacas sagradas da nossa época. In: RIBEIRO, Ivete. RIBEIRO, Ana Clara (orgs.): Família em processos contemporâneos: inovações culturais na sociedade brasileira. São Paulo: Loyola

(2003): De afinidades a coalizões: uma reflexão sobre a "transpolinização" entre gênero e parentesco em décadas recentes da antropologia. Revista Ilha. Florianópolis, v.5, n.2, p. 05-31

(2004): Família, fofoca e honra: etnografia de relações de gênero e violência em grupos populares. Porto Alegre: Editora da UFRGS. $2^{\text {a }}$ ed.

FRANKLIN, Sarah e MCKINNORT, Susan. (2001): Relative values: reconfiguring kinship studies. Durham \& London: Duke University Press.

GINSBERG, R., (1998): Mediations on Homelessness and Being at Home: In the form of a Dialogue. In: ABBARNO, G. J. M. (ed.): The Ethics of Homelessness (Vol. 86), Amsterdam: Rodopi.

HÄGERSTRAND, Torsten (1982): "Diorama, path and project". Tijdschrift voor Economische em Sociale Geographie, v. 73, n. 6, pp. 323-339.

HERBERT, Steve (2000): "For ethnography". Progress in Human Geography, v. 24, n. 4, pp. 550568.

HOLLOWAY, S. L. (1998): Local childcare cultures: moral geographies of mothering and the social organisation of pre-school education. Gender, Place and Culture 5, pp. 29-53.

(1999): Mother and worker? The negotiation of motherhood and paid employment in two urban neighbourhoods. Urban Geography 20, pp. $438-460$.

HOLLOWAY, S. L.; VALENTINE, G. (eds) (2000): Children's Geographies: playing, living, learning. London: Routledge.

INGOLD, Tim (2012): Trazendo as coisas de volta à vida: emaranhados criativos num mundo de materiais. Horizontes Antropológicos, Porto Alegre, ano 18 , n. 37, pp. 25-44.

KATZ, C. (2004): Growing up global: economic restructuring and children's everyday lives. Minneapolis, MN: University of Minnesota Press.

LATOUR, Bruno (2005): Reassembling the social. Oxford: Oxford University Press.
MALLETT, Shelley (2004): "Understanding home: a critical review of the literature". Sociological Review, v. 52, n. 1, pp. 63-89.

MARCELIN, Louis Herns (1999): A linguagem da casa entre os negros no Recôncavo Baiano. Mana [online], v. 5, n. 2 , pp. 31-60.

MASSEY, Doreen (1994): Space, place and gender. Cambridge: Polity Press.

MELLO, Sylvia Leser de (2005[1995]): "Família: perspectiva teórica e observação factual”. In: CARvalho, Maria do Carmo Brant de (org.). A família contemporânea em debate. São Paulo: EDUC/Cortez.

MOREIRA, Marianna Fernandes (2011): "Um Palacete Assobradado": Da reconstrução do lar (materialmente) à reconstrução da ideia de "lar" em uma ocupação de sem-teto no Rio de Janeiro. Dissertação (Mestrado em Geografia). Programa de Pós-Graduação em Geografia /UFRJ, Rio de Janeiro.

(2013a): A ocupação Quilombo das Guerreiras: classes populares, coletivo e família. Rio de Janeiro: Anais XIII Simpurb.

(2013b): Casa e família na geografia: estratégias espaciais de mulheres sem-teto na construção do lar. Revista Espaço e Cultura, n. 34, pp. 83-122.

(2016): Vidas em trama: geografias $d a$ família de mulheres sem-teto. Tese (Doutorado em Geografia). Programa de Pós-Graduação em Geografia /UFRJ, Rio de Janeiro.

PRATT, G. (2002): Studying immigrants in focus groups. In: P. Moss (ed). Feminist geography in practice. Oxford: Blackwell, 214-29.

SALEM, Tania (2006): “Tensões entre gêneros na classe popular: uma discussão com o paradigma holista”. Mana [online], v. 12, n. 2, pp. 419-447.

SARTI, Cynthia (1989): "Reciprocidade e hierarquia: relações de gênero na periferia de São Paulo". Cadernos de Pesquisa da Fundação Carlos Chagas, v. 70, p.38-46.

(2009): A família como espelho: um estudo sobre a moral dos pobres. São Paulo: Cortez.

STASZAK, Jean-François (2001): L'espace domestique : pour une géographie de l'intérieur//For an insider's geography of 
domestic space. Annales de Géographie, v. 110, n. 620, pp. 339-363.

VALENTINE, Gill. (2008): "The ties that bind: towards geographies of intimacies". In: Geography Compass 2: 2097-2110.

VIANNA, Adriana de Resende Barreto (2002): Limites da menoridade: tutela, família e autoridade em julgamento. Tese (Doutorado em Antropologia Social) MN/UFRJ. Rio de Janeiro.
WOORTMANN, Klaas (1987): A família das mulheres. Rio de Janeiro: Tempo Universitário.

YOUNG, I.M. (1997): House and home: feminist variations on a theme. In: Intersecting voices: dilemmas of gender, political philosophy, and policy. Princeton, NJ: Princeton University Press, 13464 .

\section{HOMELESS WOMEN AND GEOGRAPHIES OF FAMILY: INTER-HOUSEHOLD RELATIONS, GENDER AND RECIPROCITY}

ABSTRACT: DURING THE SECOND hALF OF THE $20^{\text {TH }}$ CENTURY, A NUMBER OF AUTHORS (NOTABLY IN ANTHROPOLOGY, SOCIOLOGY AND HISTORY) BEGAN TO HIGHLIGHT THE DANGER OF THE NATURALIZATION OF THE NUCLEAR FAMILY, AND

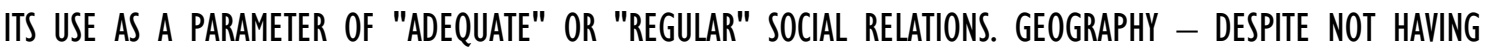
TAKEN tHE FAMILY aS AN OBJECT OF STUDY, NATURALIZING the NUCLEAR FAMILY - HAS CONTRIBUTED TO THE DISCUSSION OF THE HOME, QUESTIONING ITS UNDERSTANDING AS A PRIVATE SPHERE, SEPARATEd FROM THE WORK, CITIZENSHIP AND POLITICS. GEOGRAPHY haS, theREFORE, PROBLEMATIZED the IDEALIZED VISION OF the HOME, SEEkING tO DECONSTRUCT ITS UNIVERSAL ChARACTERISTICS. HOWEVER, THE "IDEAL HOME" IS INTIMATELY LINKED tO THE EQUALLY RESTRICTED UNDERSTANDING OF THE FAMILY: AS THE NUCLEAR FAMILY. UNDERSTANDING THAT THE SPATIALITY OF THE FAMILY DOES NOT EXHAUST ITSELF IN ITS RESIDENTIAL UNIT, BUT EXTRAPOLATES IT, WE CAN APPREHEND A GEOGRAPHY THAT INTEGRATES CHANGING COMPOSITIONS OF FAMILIAR CONFIGURATIONS, SPATIAL PRACTICES OF ALLOCATION OF PERSONS AND THINGS, AND SEXUAL ROLES WITH DISTINCT SPATIALITIES, MARKED BY THEIR PLACE IN THE HOUSEHOLD AND BY RELATIONS OF PRESENCE AND ABSENCE, PERMANENCE AND IMPERMANENCE. THIS PAPER SEEKS TO INVESTIGATE FAMILY DYNAMICS BY LOOKING AT THE TRANSFORMATIONS IN THE DOMESTIC GROUPS OVER TIME AND IN CONTEXTS CHARACTERIZED BY THE INSTABILITY OF HOUSING, AS IN THE CASE OF THE “SEM-TETO” (HOMELESS) FAMILIES. STARTING FROM THE INDIVIDUAL TRAJECTORIES OF “SEM-TETO' WOMEN, THE PAPER

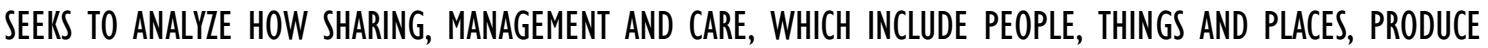
AFFECTIVITIES, PROXIMITIES AND DISTANCES THAT MAKE UP THE CONTINUOUS PROCESS OF THE FORMATION OF FAMILY AND HOME.

KEYWORDS: GEOGRAPHIES OF FAMILY; HOME; HOMELESS; RELATEDNESS; CARE 
FEMMES SANS-ABRI (“SEM-TETO”) ET LA GEOGRAPHIE DE LA FAMILLE: RELATIONS INTERMAISONNEES, GENRE ET RECIPROCITE

RÉSUMÉ: DEPUIS LE MILIEU DU SIECLE DERNIER, UN CERTAIN NOMBRE D'AUtEURS (NOTAMMENT DE

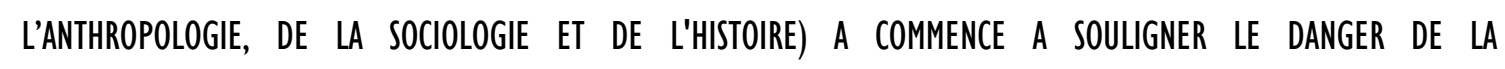
NATURALISATION DE LA faMILLE NUCLEAIRE Et SON UTILISATION COMME PARAMETRE DE RELATIONS "ADEQUATES" OU

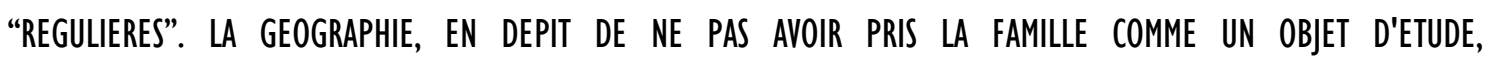
NATURALISANT LA FAMILLE NUCLEAIRE, A CONTRIBUE A LA DISCUSSION DE LA MAISON ET LE CHEZ-SOI, REMETTANT EN QUESTION SA COMPREHENSION COMME UNE SPHERE PRIVEE, SEPAREE DE LA SPHERE PUBLIQUE DU TRAVALL, DE LA CitOYenNete et de la POLITIQUE. tOUS CES tRAVAUX REMETTENT EN QUESTION LA VISION IDEALISEE DE LA MAISON, CHERCHANT A DECONSTRUIRE LeURS CARACTERISTIQUUES UNIVERSELlES. CEPENDANT, LA “MAISON IDEALE” EST ETROITEMENT LIEE A LA COMPREHENSION AUSSI LIMITEE DE LA FAMILLE: LA FAMILLE NUCLEAIRE. EN COMPRENANT QUE LA SPATIALITE DE LA FAMILle NE SE LIMITE PAS A SON UNITE RESIDENTIELLE, MAIS L'EXTRAPOLE, ON PEUT APPREHENDER UNE GEOGRAPHIE QUI INTEGRE DES COMPOSITIONS CHANGEANTES DE CONFIGURATIONS FAMILIERES, DES PRATIQUES SPATIALES D'ALLOCATION DE PERSONNES ET DE CHOSES ET DES ROLES SEXUELS AVEC UNE SPATIALITE distinCte, MARQUES PAR LE LIEU QU'ILS OCCUPENT DANS la MAISONNEE ET PAR LES RELATIONS DE PRESENCE ET

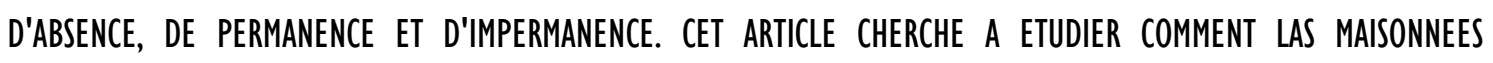
SONT CONSTRUITES dANS DES CONTEXTES MARQUES PAR L'INSTABILITE D'HABITACION, COMME DANS LE CAS DES

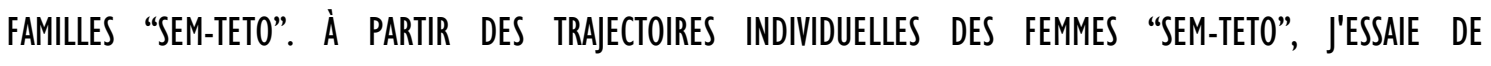
COMPRENDRE COMMENT le PARTAGE, la GESTION Et les SOINS, IMPLIQUANT LES PERSONNES, LES CHOSES Et LES LIEUX, PRODUISENT DES AFFECTIVITES, DES PROXIMITES ET DES DISTANCES QUI CONSTITUENT LE PROCESSUS CONTINU DE FORMATION DE LA FAMILLE ET DU CHEZ-SOI.

MOTS-CLÉS: GEOGRAPHIE DE LA FAMILLE; CHEZ SOI; "SEM-TETO"; RELATIONNALITE; SOIN 